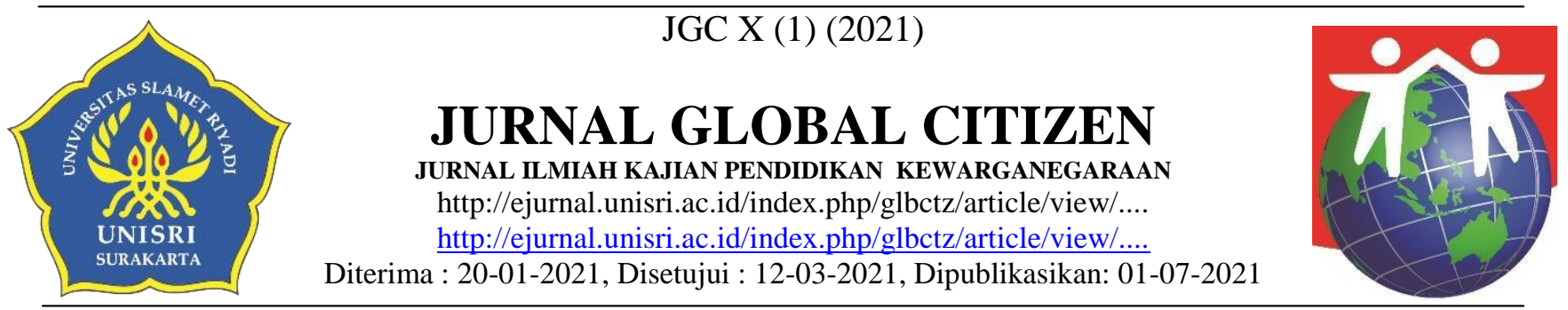

\title{
NILAI-NILAI DEMOKRASI YANG DITERAPKAN MAHASISWA SAAT PEMBELAJARAN DIMASA PANDEMI COVID- 19
}

\author{
Merlifia Monica Sari ${ }^{(1)}$,Anita Trisiana ${ }^{(2)}$,Sekar Ayu Fatmawati ${ }^{(3)}$ \\ Universitas Slamet Riyadi
}

\begin{abstract}
ABSTRAK
Covid-19 mulai muncul di daerah Wuhan, tepatnya di provinsi Hubei. Terjadinya covid19 ini di tandai dengan adanya pasar di daerah wuhan, pasar itu menjajakan berbagai makanan dan hewan mati ataupun hidup. Sekarang ini covid-19 sudah menyebar di berbagai negara yaitu Indonesia, Pertama kali covid-19 ini muncul di Indonesia yaitu di daerah Depok. Untuk mencegah penularan covid-19 maka pemerintah menghimbau program pembelajaran di lakukan dengan daring karena adanya pandemic covid-19. Seluruh universitas baik negri maupun suasta melakukan kegiatan belajar mengajar secara onlain yang biasanya di lakukan di kampus maupun sekolah. Kegiatan yang dilakukan secara onlain juga memiliki beberapa kendala yakni pengunaan jaringan internet, karena pembelajaran daring merupakan solusi yang tepat untuk mencegah terjadinya penyebaran covid-19 ini. Pemerintah saat ini juga mengeluarkan kebijakan New Normal yang tujuannya untuk menghidupkan kembali perekonomian masyarakat maupun negara yang lumpuh akibat pandemi covid-19. Metode dalam penelitian ini mengunakan metode studi perpustakaan. Kesimpulan dari hasil penelitian saat ini yaitu tentang nilai-nilai demokrasi di tengah pandemi covid-19. Untuk bisa memperoleh informasi kita bisa mendapatkan itu semua melalui prosedur yang kita gunakan dalam pengkajian yaitu penelitian kualitatif.
\end{abstract}

Kata Kunci : Covid 19, Demokrasi, Mahasiswa 


\begin{abstract}
Covid-19 began to appear in the wuhan area, to be precise in Hubei province. The occurrence of covid-19 is marked in the existence of market selling a variety of food and live or dead animals. Now covid-19 has spread in various countries, namely in the Depok area, To prevent the transmission of covid-19, the government calls for learning programs to be carried out online because of the covid-19 pandemic. All universities, both public and private, carry out other teaching and learning activities carried out online also have several obstacles, namely the use of the internet network, because online learning is the right solution to prevent the spread of covid-19. The current government has also issued a New Normal policy which aims to revive the economy of people and countries that were paralyzed by the covid-19 pandemic. The method in this research uses the library study method. The conclusion from the results of the current research is about democratic values in the mids of the covid-19 pandemic. To be able to abtain information, we can get it all through the procedures we use in assessment, namely qualitative research.
\end{abstract}

Keywords : Covid - 19, Democracy, Students 


\section{PENDAHULUAN}

Tahun ini tepatnya 2020 kita sedang diuji yaitu dengan adannya pandemic covid19, sampai detik ini pula Indonesia masih terkena dampak dari Covid19. Virus ini menular melalui sentuhan ataupun udara dan dapat menular dari manusia yang satu ke manusia yang lainnya.Covid-19 saat ini sangat di takuti oleh manusia karena virus ini dapat menyebabkan kematian. Virus ini saat menyerang seseorng maka seseorang tersebut akan mengalami ganguan pada pernafasan terutama batuk dan badan terasa panas. Sekarang ini covid-19 sudah menyebar di berbagai negara yaitu Indonesia, Pertama kali covid-19 ini muncul di Indonesia yaitu di daerah Depok. Virus ini sudah menyebar di berbagai daerah sehingga angka kematian semakin banyak. Sehingga Pemerintah menghimbau agar kegiatan termasuk sekolah dilak sanakan secara onlain, agar bisa memutus mata rantai covid-19 ini.

Dalam Kamus Besar Indonesia diartikan dalam jaringan, terhubung memlaui jejaring computer, internet, dan sebagainya. Pembelajaran daring dilaksanakan sebagai langkah tepat untuk dapat mencegah dan menekan penularan virus covid-19. Walaupun pemerintah sudah mengeluarkan kebijakan New Normal yang tujuannya adalah menghidupkan kembali sector perekonomian yang sudah kurang lebih 5 bulan lumpuh akibat dampak Covid-19, akan tetapi sektor pendidikan khususnya pembelajaran secara langsung belum sepenuhnya berani dibuka oleh pemerintah. Progam belajar secara daring ini adalah solusi yang tepat untuk menghadapi covid-19 bagi setiap universitas. kegiatan sekarang ini juga dilakukan di dalam rumah untuk menghindari penyebaran covid19. Adapu perbedaan saat sekolah terutama dalam pembelajarannya yang biasanya dilakukan secara langsung kini dilakukan dengan onlain. Perubahan itu merupakan keputusan yang dilakukan setiap universitas agar kegiatan belajar mengajar tetap terlaksana seperti biasa dengan diadakannya sekolah secara daring. Dalam penerapan pembelanjaran daring, mahasiswa juga dituntut untuk melakukan sebagai mana perannya sendiri-sendiri. Sekarang ini dosen dosen sebagai fasilisator ataupun pembimbig saat pembelajaran berlangsung. Mahasiswa juga di tuntut untuk mandiri agar tercapai tujuan yang diinginkan. Saat ini kuliah juga di lakukan secara onlain dan bisa dilakukan dimana saja sehingga mahasiswa mudah untuk mengikutinya. Pendidikan sekarang ini dilakukan dengan mengunakan internet, dengan begitu maka proses pembelajaran akan terlaksana, dan mahasiswa juga dituntut agar lebih ber kereatif dan inofatif. Mahasiswa juga harus bisa mengikuti pembelajaran secara daring dan mengunakan teknologi yang cangih.

Penerapan pembelajaran secara onlain juga dapat dilakukan oleh dosen kepada mahasiswanya agar dosen bisa memberikan materi kepada mahasiswnya. Mahasiswa juga harus bisa menerima materi yang diberikan olrh dosen. Adapun beberapa hambatan yang dialami saat perkuliahan daring adapun keluhan dari dosen dan mahasiswa. Namun juga ada beberapa kelebihan yang didapat dalam belajar daring ini. Adapun kelebihan dalam pembelajaran yaitu pembelajaran sekarang ini dapat di lakukan di tempat manapun sehingga mahasiswa dan dosen mudah untuk melakukannya. Pembelajaran ini sangatlah memanafaatkan jaringan internet sehingga setiap universitas memberikan kuota internet secara gratis kepada mahasiswanya, mahasiswa dan dosen melakukan belajar dan mengajar secara daring. Mahasiswa juga dituntut untuk mandiri karena berlajar hanya mengunakan media internet. Dosen juga akan menyampaikan informasi melalui rekaman suara maupun video.

Dalam kondisi saat ini mahasiswa juda bisa kuliah dimana saja sesuai jadwal yang diberikan oleh pihak sekolah. Beberapa materi yang diberikan dosen untuk mahasiswanya juga dilakukan secara daring. Sehingga dosen dan mahasiswa dituntut untuk bisa mengakses internet dengan baik. Beberapa dosen juga memberi waktu luang kepada mahasiswanya untuk mengumpulkan tugas. Sehingga mahasiswa mempunyai waktu yang sangat banyak dan luang. Pada saat ini menteri pendidikan memutuskan agar pembelajaran dilakukan secara daring karena pandemi covid-19. Untuk mengurangi resiko 
yang dikarenakan covid-19 maka pemerintah memberi himbauan kepada seluruh masyarakat dan mahasiswa untuk mengikuti kegiatan secara onlain. Pembelajaran yang dilakukan seperti sekarang ini belum di lakukan secara baik. Adapun beberapa kendala yang menyebabkan kesulitan serta diperlukan adaptasi yang harus dihadapi mahasiswa.

Adapun beberapa kendala dalam melakukan pembelajaran secara daring yaitu jaringan internet, jaringan internet harus inftrastruktur. Pembelajaran secara daring juga membutuhkan biayay yang tidak sedikit. Sehingga beberapa universitas memberikan kuota gratis. Beberapa kendala dalam pembelajaran onlain yaitu susahnya jaringan internet. Adapun universitas yang tidak memberikan kuota internet sehingga mahasiswa akan banyak mengeluarkan biaya untuk membeli kuota internet. Apalagi untuk mahasiswa yang sekarang ini terkena dampak covid-19 serta orang tua mereka yang tidak mempunyai penghasilan akibat pandemic covid-19. Sehingga beberapa universitas memberikan kuota tambahan secara gratis bagi mahasiswanya. Pembelajaran secara onlain juga bisa memyebabkan ganguan kesehatan terutama kesehatan pada mata. Mahasiswa juga akan mengalami turunnya motifasi belajar yang di sebabkan adanya pandemic covid-19. Sekarang ini mahasiswa juga tidak bisa mengembangkan bakatnya dikarenakan pandemic covid-19 ini sehingga mahasiswa susah untuk berinteraksi dengan dosen dan mahasiswa yang lain, Karena pembelajaran yang dilakukan secara daring.

Beberapa universitas juga mempunyai fasilitas dan sarana pendukung baik itu jangka menengah maupun jangka panjang. Sehingga mahasiswa terkena dampak tersebut. Adapun beberapa kendala yang dalam pembelajaran online. Pembelajaran onlain harus efektif agar mahasiswa bisa mencapai target-target yang telah di tentukan. Mahasiswa yang aktif dalam melakukan pembelajaran yaitu mahasiswa yang menonjol. Sehingga mahasiswa mampu mengikuti pembelajaran secara daring. Mahasiswa juga dituntut untuk mengikuti materi pembelajaran yang telah di tetapkanoleh sekolah.beberapa mahasiswa lebih memiih belajar secara tatap muka dibandingkan dengan mengunakan pembelajaran onlain. Kendala dalam pembelajaran onlain yaitu susahnya jaringan internet mengakibatkan terkendalannya pembelajaran online. Mahasiswa juga tidak bisa berinteraksi dengan dosen sehingga dosen dengan mahasiswa tidak saling berinteraksi. Seluruh mahasiswa juga dihimbau agar siap dalam menghadapi pandemi yang terjadi saat ini, agar mahasiswa mempunyai pribadi dan rasa tangung jawab yang tinggi.

Gelar yang diberikan universitas kepada mahasiswanya juga tidak sembarangan. Beberapa inovasi juga diberikan kepada mahasiswa agar mahasiswa tersebut memiliki budi pekerti. Sehingga mahasiswa juga harus selalu menerapkan nilai-nilai demokrasi apalagi di tengah pandemi seperti ini. Begitu pula mahasiswa juga selalu dihadapi dengan konflik yang begitu berat, adapun tantangan yang harus dihadapi mahasiswa. Mahasiswa juga menghadapi situasi Pandemi yaitu covid19. Suasana yang begitu keruh akan disorot oleh beberapa media, karena pandemic yang terjadi saat ini. Disisi lain masyarakat harus saling menyadari bahwa harus patuh terhadap hukun yang telah di tetapkan pemerintah. Dalam pandemi ini masyarakat dan mahasiswa dituntut untuk mempunyai rasa tangung jawab dan patriotism, untuk memutus penyebaran rantai pandemi covid-19, yaitu dengan mematuhi protocol kesehatan.

Virus ini juga dikatakan sebagai penyakit menular karena penyebarannya yang begitu cepat yaitu melalui udara. Dan penyakit ini sudah menyebar di berbagai negara termasuk Indonesia. Maka itu kita di tuntut untuk mematuhi beberapa protokol kesehatan yang telah di berikan pemerintah. Supaya kita semua terhindar dari penularan covid-19 ini. Indonesia merupakan negara dengan angka kematian tertinggi 8\% kasus ini pernah menjadi angka kematian tertinggi di ASEAN semenjak adannya covid-19. Kekompakan pemerintah dan angota kesehatan harus saling bekerja sama. Adapun upaya yang dilakukan Pemerintah yaitu dengan melakukan jaga jarak, agar bisa memutus rantai penyebaran covid-19 ini. Tim medis juga memberi saran 
kepasa masyarakat agar melakukan kegiatan di rumah saja dan dihimbau kepada masyarakat untuk tidak melakukan kerumunan saat pandemic covid-19 ini terjadi. Dan tetap melakukan protocol kesehatan.

Adapun yang semestinya dilakukan rakyat adalah bergotong royong, bersamasama menegakkan Demokrasi guna berjuang melawan pandemic covid serta mematuhi kebijakan yang ada. Pemerintah juga memberi kebijakan yaitu dengan menjaga jarak menghadapai kasus ini. Masyarakat di himbau untuk bisa mematuhi protocol kesehatan yang telah di tetapkan oleh pemerintah .Sudah ada beberapa kasus yang telah terjadi di Indonesia yaitu masih menyangkut tentang pandemic covid-19. Sekarang ini telah mengunakan scenario yaitu scenario dengan berjaga jarak, agar masyarakat bisa melakukan kegiatan secara normal jika scenario ini gagal maka akan kembali seperti awal yaitu lock down, dan menunggu sampai vaksin covid-19 ditemukan. Sehingga masyarakat bisa beraktifitas seperti biasa dengan mematuhi protocol kesehatan.Yang di namakan skenario jaga jarakialah kegiatan yang dilakukan diluar rumah dengan mematuhi protocol kesehatan dengan berjaga jarak. Segala aktifitas yang diluar ruangan maka masyarakay diwajipkan untuk mematuhi protocol kesehatan yang telah di tentuka pemerintah. Jika diterapkan social distabting maka kita akan secara perlahan mengubah gaya hidup kita menjadi jaga jarak, dan dengan mematuhi protocol kesehatan. Hanyalah melalui demokrasi, media yang bebas dapat mejalankan peran mereka dalam memberikan informasi mengenai pandemi covid-19 ini pada masyarakat dan mengawasi pemerintah dan lembaga Negara lainnya dalam upaya dan cara menangani kasus covid-19 di Indonsia. Hanya di demokrasi, data pemeerintah mengenai korban dan cara penanganan virus covid-19 ini dapat dipercaya.

\section{METODE}

Penelitian diawali dengan studi pustaka, tentang penerapan nilai-nilai demokrasi bagi mahasiswa di tengah pandemic covid-19. Virus covid-19 dapat dikatakan penyakit yang dapat menular jika kita bersentuhan dengan orang yang terkena virus tersebut maka kita akan terkena penyakit tersebut. Virus ini menyebar melalui saluran pernafasan. Virus ini biasanya menyebar melalui udara dan benda sehingga dapat mempengaruhi saluran pernafasan manusia. Penelitian ini mengunakan Studi Kepustakaan agar peneliti mudah untuk memperoleh informasi dalam mencari topic ataupun masalah yang akan di teliti. Untuk bisa memperoleh Informasi maka kita bisa mendapatkannya itu semua melalui dari berbagai sumber buku. Dalam penelitian ini ditemukan berbagai kekurangan ataupun kelebihan dalam pembelajaran online serta nilai-nilai demokrasi yang dapat dilakukan mahasiswa disaat pandemi covid-19 saat ini.

Kendala dalam pembelajaran online yaitu dosen dan mahasiswa tidak bisa berinteraksi secara langsung. Mahasiswa juga dihimbau untuk tidak saling mempunyai sifat individu. Seluruh mahasiswa juga dihimbau agar berhati-hati disaat pandemi seperti ini. Dan setiap mahasiswa wajib menjalin komunikasi dengan mahasiswa agar rasa kesatuan tetap terjaga.Prosedur yang kita gunakan dalam pengkajian ini adalah adalah prosedur kualitatif yang menjelaskan pada sudut suatu pengetian secara melekat kepada satu permasalahan dan hanya membuktikan persoalan kepada pengkajian penyamarataan. Desain pendalaman kualitatif selalu memakai teknis penjabaran yang erat (in-depth analysis). Merupakan menganalisis suatu perkara sebagai penelitian yang dapat terperinci,mulai peristiwa satu ke peristiwa lain. Sebab dalam metologi kualitatif tetap memiliki karakter suatu perkara satu bertentangan dengan karakter perkara yang lain. Sasaran mengenai penelitian kualitatif yang memiliki suatu abstraksi namun pengetahuan yang menurut insentif kepada 1 perkara.

Seperti yang dibahas pada penelitian ini dimana dampak dari covid-19 terhadap pendidikan di Indonesia terutama pada jenjang perkuliahan dimana Progam belajar secara daring memudahkan mahasiswa untuk berkomunikasi dengan dosen, sehingga setiap 
universitas menghimbau untuk belajar secara daring, jika dilakukan secara tatap muka maka kasus virus ini akan semakin banyak. Pemebelajaran sekarang ini dilakukan secara daring agar dosen bisa mengajar mahasiswanya. Adapun beberapa perubahan dalam melakukan pembelajaran, sehingga mahasiswa harus mengalami adaptasi, yang biasanya dilakukan secara tatap muka sekarang menjadi online. Seluruh universitas menghimbau agar perkuliahan dilakukan secara daring. Agar pembelajaran bisa terlaksana dengan baik.

Selain menggunakan metode kualitatif kami menggunakan metode penelitian deskriptif. Metode deskriptif bias dijelaskan yaitu tentang langkah-langkah memecahkan permasalahan yang diteliti melalui penggambaran kondisi subyek seperti manusia, lembaga-lembaga, dan masyarakat. Pembelajaran daring tentunya membuat mahasiswa mengeluarkan uang untuk membeli kuota internet, sehingga setiap universitas memberikan kuota internet secara gratis untuk seluruh mahasiswa yang belajar secara daring. Sehingga bisa meringankan beban orang tua, yang orang tuanya terkena dampak covid-19. Penelitian ini mengunakan metode deskriptif yaitu metode yang digunakan untuk penelitian status kelompok orang, pada system pemikiran atau suatu kejadian saat ini. Tujuan penelitian ini yaitu suatu kebenaran atau keterkaitan melalui peristiwa yang di teliti, adapun beberapa metode menurut beberapa ahli. Sehingga peneliti lebih luas untuk menemukan hasil penelitiannya, metode deskritif yaitu metode untuk menganalisis hasil penelitian digunakan untuk membuat kesimpulan yang lebih luas.

\section{PEMBAHASAN}

Pada bulan desember 2019 di kota Wuhan,China dilaporkan telah muncul pertama kali virus corona jenis baru atau SARS-CoV-2. Virus ini dengan cepat menyebar ke hamper seluruh dunia, dikatakan bahwa virus ini menyebabkan terganggunya sistem pernafasan. Gejala ringan yang ditimbulkan dari virus corona ini seperti batuk,pilek,demam,sakit tenggorokan, serta gejala berat seperti sesak nafas. Virus corona ini apabila fatal bias menyebabkan kematian. Virus corona ini menyebar dengan cepat dalam jangka waktu 3 bulan sejak dilaporkan pertama kali di kota Wuhan,China.Virus corona sudah mulai masuk ke Indonesia dan daerah yang pertama terdapat kasus di wilayah Depok. Organisasi kesehatan dunia telah mengumumkan bhawa virus corona/covid-19 sebagai pandemic global karena cepatnya penyebaran viarus ini.Banyak negara di dunia menerapkan sistem lockdown untuk mengurangi penyebaran virus corona agar tidak terlalu cepat berkembang, segala akativitas masyarakat yang akan keluar atau masuk ke dalam negeri akan ditutup. Namun di pemerintah di Indonesia tidak sepenuhnya melakukan lockdown seperti negara-negara lain,pemerintah hanya menerapkan pembatsan social berskala besar (PSBB) di beberapa wilayah. Masyarakat diharuskan untuk berada dirumah dan mengurangi aktivtas di luar rumah dimana berkerja,belajar dan beribadah dilakukan dirumah. Dengan adanya pembatsan social dan membatasi diri untuk tetap tinggal dirumah dapat menimbulkan beberapa akibat. Sebenarnya dengan adanya pembeatsan social ini dapat membantu dalam memutus rantai penyebaran virus corona,namun hal ini malah menimbulkan dampak negatife,terutama disektorperekonomian dan pendidikan. Di bagian perekonomian telah banyak karyawan yang di PHK oleh pabrik maupun industri di tempat meraka bekerja hal ini menyebabkan banyak masyarakat yang kehilangan pekerjaanya.

Virus corona/Covid-19 adalah virus yang telah menjadi pandemic dan telah menggemparkan hampir diseluruh dunia. Di Indonesia angka kematian akibat Covid-19 mencapai $8 \%$ dan semakin meningkat hal ini menjadikan Indonesia masuk kedalam kasus kematian akibat covid-19 yang tertinggi di ASEAN. Perlu kerja sama yang seimbang antara masyarakat,tenaga medis, dan pemerintah guna menurunkan kasus peningkatan akibat covid-19 dan mempersempit penyebaran viruscovid-19 ini. Strategi pemerintah untuk mengurangi peningkatan kasus covid-19 dengan 
memberlakukan social distancing dengan berdiam diri dirumah,belajr dirumah,bekeraj dirumah serta menutup segala aktivitas dan kegiatan yanag mengumpulkan orang banyak dan menyebabkan kerumunan. Selain itu, pemerintah juga melakukan pembatasan bahkan pelarangan untuk melakukan perjalanan ke luar ataupun ke dalam negeri. Edukasi dan promosi kesehatan dilakukan pemerintah tentang cara bagaimnaa menghambat penyebaran virus covid-19 di media social maupun dilakukan secara umum hal ini dilakukan agar masyarakat dapat memperoleh informasi dengan benar dan sesuai anjuran pemerintah mengena kasus covid-19 ini.

Wabah virus corona atau covid-19 telah melanda hampir di seluruh dunia hal ini memberikan tantangan tersendiri bagi lembaga pendidikan,khususnya untuk lembaga pendidikan di perguruan tinggi baik negeri maupun swasta. Untuk mengatasi penongkatan kasus covid-19 ini pemerintah mengeluarkan kebijakan untuk tidak adanya aktivitas berkeruman,social distancing, cuci tangan,memakai masker. Menurut surat edaran Kemendikbud Dikti No.1 tahun 2020 kementrian pendidikan dan kebudayaan serta pemerintah melarang perguruan tinggi maupun sekolah melaksanakan kegiatan pembealajaran dengan tatap dan diganti dengan sistem pembelajaran online/daring. Pembelajaran daring mampu mempertemukan mahasiswa dan dosen tanpa bertemu langsung dan melakukan interaksi melalui media seperti handphone, laptop, computer dengan bantuan internet dan yang terdambung ke jaringan internet.

Dosen maupun mahasiswa melalukan interaksi pembelajran melalui teknologi. Kebijakan system pembelajaran daring ini menjadi hal yang tentu membuat para dosen maupun mahasiswa harus membiasakan diri terhadap perubahan sistem pembelajaran yang biasanya tatp muka menjadi system pembelajaran daring. Dalam penggunaan system pembelajaran daring ini kesehatan lahir dan batin bagi dosen dan mahasiswa menjadi pertimbangan utama bagi universitas. Walaupun segala aktivitas di universitas telah diliburkan bukan berarti pembelajaran ikut
diliburkan,Kemendikbud telah menjelaskan bahwa pe,belajaran yang pada awalnya dilakukan di kampus hanya dipindah dan dilakukan dirumah masing-masing serta proses pemeblajaran tetap dilakukan seperti biasa namun hanya melalui media virtual.

Di lingkungan universitas telah gencar dilakukan berbagai cara dan aturan untuk mencegah rantai penyebaran covid-19 dengan menerapkan aturan pembelajaran secara daring. Semua kegiatan dilakukan menggunakan akses internet dan bantuan alat digital seperti handphone,laptop,dll agar memudahkan dosen dan mahasiswa dalam berinteraksi secara online walaupun tanpa adanya tatap muka. Bahan ajar yang diberiakan dosen kepada mahasiswa dapat berupa video,audio,PPT,file yang mana semua itu dapat dengan mudah diberikan dan para mahasiswa dapat mengakses kapanpun dan dimanapun saja. Akibat dari keberadaan mahasiswa dan dosen yang berbeda tempat dan tanpa adanya kontak fisik maupun interaksi langsung mampu memunculkan perilaku social distancing. Dimana melakukan social distancing adalah salah satu cara dan solusi terbaik dalam mencegah penyebaran virus corona. Mahasiswa dan dosen melakukan sistem perkuliahan dari rumah mereka masing-masing hal inilah yang menjadi bentuk sistem perkuliahan secara daring..Mengirim tugas ataupun memperoleh materi dapat dilakukuan oleh mahasiswa melalui media handphone,laptop,computer,ddl tanpa mereka harus dating ke kampus. Dengan sistem pembelajaran secara online bisa mengurangi aktivitas dan kerumunan massa yang berada di kampus seperti yang terjadi pada masa pembelajaran secara tatap muka. jaga jarak antara yang lain dapat mengurangi kasus penyebaran virus corona/covid-19 hal ini sesuai yang telah dijelaskan WHO.

Di era globalisasi pemanfaatan teknologi dapat dimaksimalkan dan dimanfaatkan apalagi dalam kondisi pandemic covid-19 seperti ini. Dengan adanya sistem pembelajaran online dapat meberikan banyak peluang untuk mahasiwa agar mereka bisa mengakses apapun bahan pembelajaran yang mereka inginkan. Banyak 
plaatfoam ataupun media online yang dapat diakses untuk bahan pembelajaran oleh mahaiswa maupun dosen melalui internet. Namun ada sebagian hal yang menimbulkan hambatan dalam sistem pembelajaran secara online ini seperti keterbatasan kuota internet yang dimiliki mahasiwa danmasih belum terbiasanya dosen ataupun mahasiwa dalam penggunaan aplikasi atau media dalam sistem pembelajaran online ini. Pembelajaran online/daring membriakan hal yang menyenangkan bagi mahasiwa karena meraka dapat melakukan pembelajaran dengan melalui smartphone,computer,laptop bukan hanya sekedarmenyimak buku.

Instusi pendidikan tertinggi di Indonesia yang merupakan universitas harus dan wajib cepat tanggap dalam menangani dan menghadapi permasalahan virus covid-19 yang melanda Indonesia. Menurut mahasiwa kegiatan perkuliahan yang tidak dilakukan melalui pertemuan fisik atau dilakukan secara online lebih sulit untuk diserap mahasiswa. . tidak semua dosen ahli dalam menggunakan teknologi dalam perkuliahan online ini , tetapi setiap pengelola kampus dengan cepat memberikan pelatihan tentang penggunaan teknologi kepada dosen yang belum bisa menggunakan teknologi secara maksimal. Hal ini sangat direspon oleh dosen dengan cepat terutama dosen yang sudah berumur demi mengoptimalkan dalam pembelajaran online ini.Tidak semua dosen dapat menyerap dan memahami dalam penggunaan teknologi. Mahasiswa juga memiliki kemampuan yang berbeda-beda dalam menyerap setiap materi pembelajaran. Dosen memberikan tugas yang banyak dan terus menerus sedangkan terkadang mereka tidak menjelaskan tentang mteri perkuliahan hal inilah yang sedikit menjadi kendala bagi mahasiswa. Hal ini juga menjadi kurang adil dan bijaksana untuk dilakukan oleh dosen. Mahasiwa berpendapat apabila dosen memberikan materi power point yang ditambahkan dengan audio/suara mungkin dapat lebih memudahkan dan membantu mahaiswa, sehingga mahasiswa tidak hanya melihat materinya saja tetapi sekaligus mendengarkan penjabaran dari materi yang diberikan.

Ketersediaan layanan internet/kuota internet juga menjadi tantangan tersendiri dalam pelaksanaan pembelajaran daring ini, banyak mahasiswa yang menggukan kuota pribadi dan wifi mereka untuk mengakses pembelajaran. Di saat ini, hampir seluruh masyarakat menggunakan internet untuk melakukan aktivitas dan pekerjaan mereka akibatnya jaringan internet menjadi lebih lambat terkadang hampir tidak bisa uantuk digunakan karena telah ada banyak orang yang meggunakannya. Hal ini menyebabkan terkadang mahasiswa banyak yang terlambat untuk mengikuti pembelajaran online karna terkendala sinyal internet. Berkenaan dengan penerapan nilai-nilai demokrasi,tertib dan disiplin dalam mengikuti setiap kegiatan perkuliahan dari rumah masing-masing adalah salah satu bentuk dalam penerapan nilai-nilai demokrasi yang dapat dilakukan mahasiswa ditengah pandemic seaperti ini. Mahasiswa diharapkan dapat disiplin dan mandiri dalam mengelola waktu belajar mereka agar dapat sesuai dengan dengan apa yang dikelola oleh program studinya apalagi di tengah pandemic seperti ini dengan sistem perkuliahan tidak dengan tatap muka secara langsung. Dengan demikian diharapkan bagi mahasiswa yang merasa ridak disiplin dan mandiri perlu mendapat perahtain yang lebih dan diberi pemahaman yang lebih agar mereka lebih aktif dan efektif tujuannya agar mahasiswa mamapu menerapkan nilai-nilai demokrasi dengan baik walau di tengah pendemi covid19 dan juga dihaarapkan nilai-nilai demokrasi yang ada dalam diri mahasiwa semakin kokoh dan kuat.

Tantangan lain yang dihadapi dalam pembelajaran dengan sistem daring ini adalah masalah pembiayaan dalam pembealajran daring. Mahasiswa banyak menceritakan bahwa dalam mengikuti pembelajaran daring ini mahasiswa perlu mengeluarakn biaya yang lumayan banyak untuk mmebeli kuota internet. Bahkan menurut mahasiwa apabila menggunakan video dalam pembelajaran akan lebih banyak menguras kuota dan menghasikan kuota internet mereka dibandingkan dengan pembelajaran dalam bentuk diskusi online melalui pesan instan. Mahasiwa rata-rata mengeluarkan biaya untuk membeli kuota internet sebanyak Rp.100.000 
sampai Rp.200.000 per minggunya,tergantung bagaimana penggunaan dalam sistem pembelajaran yang digunakan. Kesulitan lain yang ada pada saat pembelajaran online bukan hanya tentang permasalahan penggunaan teknologi tetapi juga terkait beban kuliah mahasiswa yang lebih banyak dan berat yang harus dilakukan mahasiswa karena ada banyak mata kuliah yang harus dihadapi oleh mahasiswa apalagi saat ini terkendala dalam pandemic covid-19 ini. Hal ini dikaranakan mahasiwa sudah terbiasa dengan pembelajaran secara langsung/tatap muka daripada dengan pembelajaan secara online. Permasalahan dapat muncul tersendiri bagi para mahasiswa akibat dari adanya perubahan sistem pembelajaran.

Di saat pembelajaran daring seperti ini banyak muncul tekanan dan stress pada mahasiswa, apalagi pada saat ini tekanan tentu akan terasalebih berat sehingga banyak mahasiswa yang melakukan copping stress dimana salah satunya adalah penggunaan media social yang berlebihan.seharusnya media social dapat menjadikan cara dalam menghadapi rasa bosan ataupun stress yang dirasakan mahasiswa karena belajar dirumah. Keadaan menjadi sangat berbeda apalagi ditengah pandemic covid-19. Kelebihan informasi telah menyebabkan social media fatigue karena membebani kondisi individu yang ditandai dengan jarang atau tidak lagi mengakses media social yang mereka miliki semacam facebook,twitter,instagram atau bahkan menutup atau deaktivasi akunnya.

Pembelajaran secara daring juga memberikan tantangan tersendiri,dosen tidak dapat memperhatiakan mahasiswanya secara langsung dalam proses pembelajaran karena perbedaan lokasi mereka. Dosen tidak dapat menjamin bahwa mahasiswa mendengarakan dan bersungguh-sungguh dalam mendengarkan materi yang diberikan. Dalam perkuliahan daring mahasiswa lebih banyak melamun dan kurang fokus dalam belajar dibandingkan dengan kuliah secara langsung/tatap muka. Sebaiknya apembelajaran secara online dilakukan dalam waktu yang tidak terlalu lama mengingat bahwa banyak mahasiswa yang akan gagal fokus dan kurang konsentrasi apabila dilakukan dalam waktu yang lama. Mahasiwa merasa banyak kesulitan dalam menerima materi perkuliahan yang dilakukan secara daring ini. Pembelajaran dalam sistem daring biasanya dosen akan menyampaikan dalam bentuk bacaan dan mahasiwa banyak kurang mendengarkan dan tidak mudah dapat dipahami secara keseluruhan materi yang diberikan oleh dosen.

Mahasiswa berpendapat bahwa perlu adanya penjelasan secara langsung oleh dosen karena apabila hanya diberi tugas saja mahasiswa kurang paham tentang materi perkuliahan yang diberikan.Banyak mahasiwa yang mengeluh karna adanya banyak tugas yang diberikan dosen yang tanpa penjealsan membuat meraka kewalahan dan merasa kurang paham tentang materi perkuliahan yang diberikan akibat sistem pembelajaran secara online ini. Bahkan aplikasi yanga digunakan mahasiswa dalam pembelajaran online ini masih ada yang membingungkan mahasiswa. Sistem pemeblajaran online ini membutuhkan adaptasi dan pemahaman yang ekstra agar proses pembelajaran dapat berjalan sesuai yanag diinginkan. Pada saat ini banyak dosen menggunakan lebih dari satu aplikasi bahkan menggabungkan beberapa aplikasi dalam memberiakan materi perkuliahan kepada mahasiswa hal itu dilakukan agar mempermudah dalam proses pembelajaran dan mahasiswa mampu lebih paham tentang materi yang diberikan. Hal lain yang perlu diperahatikan dalam pembelajaran online adalah bagaimana model dan cara penyampaian yang diberikan oleh dosen kepada mahasiswa. Walaupun pembelajaran secara online lebih mengedepankan menggunakan aplikasi tetapi dosen juga harus paham metode yang akan mereka gunakan dalam memberikan materi kepada para mahasiswa,karena apabila dosen tidak mempersiapkan scenario pembelajaran yang akan dilaksanakan dan diberikan akan menyulitkan mahasiswa dalam menerima materi perkuliahan mengingat proses pembelajaran ini dilaksanakan tanpa adanya tatap muka secara langsung melainkan melalui online.

Dosen memiliki pemahaman dan pemikiran bahwa belajar adalah memberikan 
ilmu dan pengetahuan kepada mahasiswa,namun kenyataannya pendapat itu salah karena hal ini dapat mengakibatkan mahasiswa menjadi tidak produktif dan tidak aktif dalam mengmebangkan kemampuan yang dimilikinya. Maka dari itu perlu adanya pengertian tentang belajar bahwa belajar merupakan tempat untuk mengembangakan dan memberi kebebasan kepada para mahasiswa dalam mengembangkan setiap potensi yang dimilikinya. Dalam masa pandemic covid-19 ini permasalahan mental yang dihadapi mahasiswa yaitu stress. Hal ini dapat menyebabakan menurunnya kemauan dan motivasi mahasiswa dalam mengikuti proses pembelajaran sehingga mereka tidak bisa secara maksimal menerima materi yang diberikan.Seharusnya mahasiswa bisa melakukan interaksi social sehingga dapat mengembangakan minat dan bakat mereka serta dapat melakukan kegiatan organisasi yang meraka inginkan tidak secara online melaikan interaksi langsung. Motivasi belajaar yang menurun juga mengakibatkan turunnya pemahaman materi yang diterima oleh mahasiswa. Hal tersebut dapat dilihat dari kebanyakan mahasiswa yang harus mencari materi sendiri dan mereka juga dituntut untuk dapat memilih berbagai materi perkuliahan dan harus juga memepertsnggungjawabkan kebenarannya hal ini menandakan bahwa tidak sepenuhnya mahasiswa mampu paham tentang materi yang diberikan.

Disisi lain,walaupun mahasiswa dituntut untuk aktif dalam memahami materi dan lebih bersifat mandiri mereka juga harus perlu arahan dari dosen agar materi yang telah mereka terima tidak terjadi kesalahan. Apabila pengetahuan materi mereka tidak berjalan dengan baik maka pemahaman tentang materi program studi mereka juga tidak akan berhasil dengan baik. Hal ini dapat menyebabkan kesehatan mental mahasiswa terganggu. Motivasi belajar bagi mahasiswa juga berpengaruh dengan kemampuan mereka dalam dunia kerja nanti. Sebaiknya semua perguruan tinggi dapat menyediakan layanan kesehatan mental online untuk menerima segala keluhan mahasiswa dalam menjalankan pembelajaran secara daring ini.
Dengan adanya layanan kesehatan mental online ini diharapkan mahasiswa dapat dengan mudah menyampaikan keluhan yang meraka alami dalam menghadapi pembelajaran online ini.

Kebijakan lembaga pendidikan dengan menutup sementara berbagai kegiatan dan fasilitas dalam jangka waktu tertentu mengakibatkan banyak mahasiswa yanag terdampak,khususnya bagi mahasiswa yang tinggal didaerah yang kekurangan akan insfrastruktur. Walaupun ada kendala, mahasiswa diharapkan lebih aktif agar pembelajaran online dapat dikatakan lebih efektif hal ini dapat dilakukan dendan lebih banyak interaksi yang dilakukan mahasiswa kepada dosen, jadi bukan hanya berapaku saja terhadap dosen. Salah satu ciri utama dalam pembelajaran online ini adalah adanya keaktifan dan kemauan mahasiswa untuk mengarahkan bagaimana agar proses perkuliahan dapat dilaksanakan secara efektif dan optimal serta mengarahkan bagaimana metode yang digunakan yang mereka inginkan dalam pembelajaran. Pembelajaran online dapat dengan mudah diakses menggunakan laptop,handphone maupun computer. Walaupun dengan adanya kemudahan tersebut banyak mahasiswa yang mengatakan dan berepndapat bahwa mereka lebih setuju dengsan sistem perkuliahan secara offline dibandingkan dengan sistem pembelajaran online.Hal ini dikarnakan dalam perkuliahan secara online menyebabkan kurang adanya komunikasi dan interaksi yang dilakukan mahasiswa dan dosen seacara langsung hal ini dapat mneyebabkan miskomunikasi antara dosen dan mahasiswa. Sesuai dengan penerapan nilai-nilai demokrasi rasa persatuan dan kesatuan dapat semakin meningkat dengan adanya interaksi social secara langsung sehingga rasa kebrsamaan,gotong royong dan kekeluargaan di antara mahasiswa dengan dosen maupun mahasiswa dengan mahasiswa dapat terjalin dengan baik. Dimasa pandemi covid-19ini mahasiswa diharapkan tidak akan menjadi pribadi yang individual dan rasa nasionalisme tetap ada dalam diri mereka.Diharapkan mahasiswa harus selalu menjalin komunikasi dan berdiskusi tentang berbagai permasalahan 
baik masalah perkuliahan maupun tidak dengan teman-teman mereka bahkan dapat dilakukan dengan dosen. Rasa persatuan, kesatuan dan nasionalisme meraka harus tetap terjalin serta tetap kuat dan tertanam dalam diri mereka meskipun semua kegiatan dilakukan secara online.

Tujuan dengan adanya kuliah secara online ini untuk memberikan pengetahuan yang lebih kepada masyarakat Indonesia agar dapat menikmaati sistem pembelajaran dimanapun dan kapanpun saja. Dengan adanya perkuliahan dengan menggunakan internet,akan menjadikan para mahasiswa serta dosen untuk lebih aktaif dan kreatif dalam meneriama berbagai pengetahuan serta dapat memanfaatkan berbagai teknologi yang ada untuk menambah wawasan di dalam bidang mereka maupun diluar bidang mereka.Dengan adanya kondisi seperti ini memudahkan mahasiswa untuk memilih tugas mana yang mereka kerjakan terlebih dahulu dan dapat dengan bebas mengikuti mata kuliah yang mereka inginkan. Kemudahan fleksebilitas tempat,waktu dan metode pembealajaran yang ada berpengaruh terhadap kepuasan mahasiswa dalam mengahadapi pembelajaran online.

Pembelajaran secara daring tidak hanya memiliki kekurangn namun juga memiliki beberapa kelebihan yaitu mampu menumbuhkan kemandirian belajar bagi mahasiswa.Dalam pembelajaran daring lebih fokus kepada mahasiswa yang dapat mneyebabkan meraka lebih mampu bertanggung jawab dalam belajar. Selain itu dalam pembelajaran daring ini lebih bersifat mandiri. Dosen dapat memberikan materi dalam bentuk audio,video,animasi,teks dan juga hal ini dapat memudahkan mahasiswa untuk mengunduh materi yang diberikan oleh dosen. Dengan pembelajaran secara daring membuat mahasiswa memperoleh ilmu baru dengan dapat mengirim email,mengirim komentar pada mahasiswa lain hingga link video conference untuk melakukan komunikasi. Kegiatan kuliah daring ini memangdapat dilaksanakan dimanapun dan kapanpun saja sesuai ketentuan bersama. Diwaktu longgar mahasiswa dapat dengan mudah mengulang dan mempelajari materi yang telah diberikan oleh dosen. Di tengah era globalisasi yang menuntut manusia untuk hidup beradampingan dengan teknologi diharapkan juga bagi para dosen maupun mahasiswa dapat lebih memahami dan mengenal teknologi agar tidak tertinggal dengan yang lain. Dengan pembelajaran online diharapkan mahasiswa dapat lebih rileks dan santai dengan cara meraka masingmasing agar mudah menerima setiap materi yang diberikan oleh dosen serta agar para mahasiswa tidak merasa terbebani asalkan meraka semua dapat paham dan tidak melanggar peraturan yanag telah ditentukan.Sistem perkuliahan secara daring bagi bebrapa mahasiswa mampu memberikan waktu luang sehingga meraka dapat melakukan kegiatan lain yang bermanfaat, mahasiswa juga dapat sambil bekerja ataupun membuka usaha di sela-sela kosong kegiatan dalam pembelajaran online ini.

Mahasiswa merasa lebih mudah dalam menyampaikan pendapat dan merasa lebih nyaman dalam mengajukan pertanyaan selama masa kuliah online. Biasanya apabila kuliah tatap muka mahasiswa da yang merasa tekanan psikologis dari teman sebaya mereka namu melalui pembelajaran dari rumah ini meraka merasa sedikit tidak tertekan secara psikologis. Melalaui media virtual yang menyebabkan tidak ada hadirnya dosen secara langsung menjadikan mahasiswa menjadi tidak takut dalam mengemukakan pendapat dan pertanyaan meraka. Keterbatasan dalam hal tempat menjadikan mahasiswamerasa lebih mudah dalam mengemukakan gagasan meraka. Pembelajaran daring membuat mahasiswa menjadi lebih berani mengemukakan pendapat dan pertanyaan meraka secara bebas serta dapat mampu menghilangakan rasa canggung yang dialami meraka selama ini. Pembelajaran daring dapat mempengaruhi kemampuan literasi bahasa mahasiswa, keuntungan dapaat diterima mahasiswa dalam pembelajaran online ini dimana mahasiswa dapat memunculkan pembelajaran yang lebih kreatif dan efektif serta materi perkuliahan yang dapat meraka akses kapan saja dengan bantuan teknologi sangat baik yang ada pada saat ini. Mahasiswa yang memiliki kemampuan dsar 
berbahasa yaitu membaca dan menulis dianggap melakukan literasi. Sedangkan sumber baca dan tulis meraka tidak akan terlepas jauh dari teknologi dan jaringan internet seperti smartphone,computer,dan laptop.

Di Indonesia demokrasi selalu menjadi bagian dari sistem yang memposisiskan rakyatnya tidak hanya sebagai objek tetapi juga sebagai subjek. Suara rakyat apapun itu hasilnya dan menyangkut hajat hidup orang banyak berarti itu akan menjadi keputusan yang akan diberlakukan oleh warga negara dan ditetapkan oleh pemerintah. Dalam demokrasi terdapat konsep "will of all" apabila konsep tersebut dihilangkan dan dikesampingkan maka akan menimbulkan hal yang merupakan cara akan pengingkaran konsep suaatu demokrasi yang telah disepakati bersama. Jati diri demokrasi di masa pandemi ini nampaknya perlu dipertanyakan kembali..Harus diakui bahwa krisis pandemi ini telah merubah wajah lini kehidupan berbangsa dan bernegara diberbagai sektor. Lebih jauh itu bahwa krisis pandemi ini juga merubah tatanan sistem politik dan pendidikan yang semestinya berjalan.Namun keselamatan warga negara dan krisis perkeonomian pada saat pandemic covid-19 seperti ini menjadi hal yang lebih penting dari itu semua..Tatanan sistem politik dan pendidikan berubah adalah hal yang dimaklumi karena bagaimanapun keadaanya negara memiliki tanggung jawab atas keselamatan warganya karena bekerja atas nama rakyat. Pengabaian keselamatan warga negara sama halnya dengan mengabaikan rakyat dan menolak jati diri demokrasi yang sesungguhnya.

Pemerintah sebagai wakil rakyat memutuskan dan mengeluarkan berbagai kebijakan yang bersangkutan dengan pembatasan aktifitas fisiik di lingkungan social melalui musyawarah guna menghambat penyebaran virus covid-19, tentunya dengan berbagai ketentuan dan pertimbangan bersama yang sesuai dengan penerapan demokrasi. Sebagai rakyat,tidak sepatutnya kita menyalhkan salah satu pihak saja dan menjadikan suatu pihak sebagai sumber permasalahan. Pada awalnya semua kebijakan seakan tidak memilikikeadilan,namun seiring berjalannya waktu kebaikan didapatkan. Adapun yang semestinya dilakukan rakyat adalah bergotong royong, bersama-sama menegakkan Demokrasi guna berjuang melawan pandemic Covid-19 serta mematuhi kebijakan yang dikeluarkan pemerintah. Pemerintah akan mengeluarakan kebijakan new normal untuk menghadapi pandemic covid-19 ini, masyarakat diharapkan dapat secara hidup secara seimbang dan selalu taat mematuhi protocol kesehatan yang telah dikeluarkan oleh pemerintah. Dalam membuat hukum ditengah pandemic covid19,pemerintah tidak boleh meninggalkan hukum dalam membuat setiap kebijakan,apabila hukum ditinggalkan maka trias tujuan hukum yakni kepastian,keadilan dan kemanfaatan akan menjadi rusak. Hukum wajib menjadi pondasi serta perekat untuk menhasilkandan memutuskan segala keputusan yang lebih baik. Dengan catatan,hukumnya harus dibuat sesuai dengan ketentuan demokrasi serta dengan asas-asas dan prinsip-prinsip hukum. Ditengah pandemic seperti ini demokrasi menjadi batu uji bagi pemerintah dan masyarakat untuk bergotong royong dan bersama-sama saling menghadapi dan mneghambat penyebaran virus corona. Pandemi akan cepat usai apabila kita bersama-sama dewasa mwnghadapinya.

Pandemic covid-19 yang sekarang merebak bermula dari sebuah Negara yang arus infomasinya tidak mengalir secara bebas. Peringatan yang awalnya dilihat sebagai penyebarab rumor yang awalnya dilihat sebagai penyebaran rumor yang berbahaya bagi Negara. Ketika suara-suara warga Negara bertanggungjawab diredam,maka hasilnya dapat berakibat fatal,tidak hanya bagi satu Negara tertentu,tetapi bagi seluruh dunia.Sistem pemerintahan yang paling tepat untuk mengatasi krisis yang sebesar dan sekompleks covid-19 ini adalah demokrasi. Hanyalah melalui demokrasi, masyarakat dapat membangun kepercayan diri untuk tegar menghadapi sebuah krisis,menjaga ketahanan nasional di tengah kisruh pandemic covid-19 ini.Hanyalah melalui demokrasi, media yang bebas dapat mejalankan peran mereka dalam 
memberikan informasi mengenai kasus virus covid-19 dengan benar pada masyarakat,mengawasi pemerintah dan lembaga Negara lainnya dalam menangani pandemic covid-19 ini,serta melawan disinformasi yang bertujuan untuk memecahbelah masyarakat. Hanyalah di demokrasi, hukum dapat melindungi kebebasan individu dari gangguan Negara akibat pembatasan yang berlebihan dari pemerintah demi mengatasi pandemic ini.

Hanya di demokrasi, data pemeerintah akan lingkup dan dampak kesehatan dari pandemi dapat dipercaya. Demokrasi tidak menjamin adanya kepemimpinan yang kompeten dan pemerintahan yang efektif. Ketika Negara-negara demokratis secara berlomba-lomba untuk dapat cepat menghadapi dan mengatasi virus covid-19, ada Negara-negara demokratis yang berlaku buruk dalam mengatasi pandemi ini hingga membuat tinggi tingkat hilangnya nyawa dan jatuhnya ketahanan ekonomi. Namun kekuartab utama demokratis adalah kemampuannya untuk mengoreksi diri. Krisi covid-19 ini adalah tanda peringatan mendesak yang menunjukkan bahwa kebebasan yang kita rayakan terancam dan kita mesti melindunginya. Melalui demokrasi, masyarakat bersama pemimpin pilihannya dapat belajar dan tumbuh untuk menghadapi virus covid-19 ini. Virus covid-19 menjadikan permasalahan global yang signifikan,dimana demokrasi pada saat ini terancam dan seharusnya kita dapat peduli dengan selalu mengumpulkan solidaaritas kita untuk membela demokrasi dimana hal ini sesuai dengan nilai-niai demokrasi yang seharusnya selalu diterapkan. Karena saat ini di tengah pandemic covid-19 Kebebasan, kesehatan, dan kehormatan masyarakat dimanapun dipertaruhkan.

\section{KESIMPULAN}

Pada akhir tahun 2019 seluruh dunia di gemparkan dengan berita covid-19 yang ada berada di cina. Virus ini menyerang manusia melalui benda dan udara dan akan menyerang tubuh manusia melalui saluran pernafasan, dan virus ini sudah mulai menyebar di berbagai belahan dunia termasuk
Indonesia. Covid-19 sekarang ini masih menjadi pandemi yang telah benyak memakan korban sehingga meningkatnya angka kematian di seluruh dunia. Agar terhindar dari virus ini maka kita harus menerapkan protocol kesehatan dengan mengunakan masker, pandemic ini sekarang telah menyebar di berbagai belahan dunia, sehingga proses belajar mengalami kendala, dan setiap universitas menerapkan sekolah dengan mengunakan internet yaitu online. Pemerintah juga menghimbau kepada setiap universitas agar tidak kuliah dengan tatap muka, agar bisa memutus rantai penyebaran covid-19. Kebijakan sistem pembelajaran daring ini menjadi hal yang tentu membuat para dosen maupun mahasiswa harus membiasakan diri dengan pembelajaran secara daring, agar proses belajar mengajar tetap terlaksana. Sistem pembelajaran secara online memberikan banyak peluang untuk mengakses bahan pembelajaran untuk para mahasiswa.

Ada berbagai kekurangan maupun kelebihan dalam melaksanakan kuliah daring, kelebihan dari kuliah daring yaitu mahasiswa bisa mengikuti pelajaran, dan lebih santai sehinggga mudah untuk di lakukan dirumah, sedangkan kekurangannya yaitu mahasiswa susah mengakses jaringan internet sehingga menjadi kendala saaat pembelajaran online tersebut. Pembelajaran online juga memerlukan boiaya tidak sedikit sehingga mahasiswa lebih memilih kuliah ofline, apalagi yang pekerjaan orang tuannya terkena dampak covid-19. Dalam mengikuti kuliah secara darig mahasiswa mengatakan mereka harus lebih banyak mengeluarakan uang untuk membeli kuota internet agar bisa mengikuti perkuliahan. Kesulitan muncul pada saat pembelajaran daring bukan hanya dalam hal biaya, tetapi kendala jaringan dalam kuliah daring membuat mahasiswa menjadi terkendala saat pembelajaran dilakukan.

Dalam pembelajaran daring mahasiswa memiliki tantangan tersendiri, dosen dan mahasiswa melakukan pembelajaran dengan berbeda tempat danterpida dalam melaksanakan pembelajaran, sehingga mahasiswa lebih sulit untuk melakukan 
pembelajaran secara daring ini. Tidak ada jaminan bahwa mahasiswa sungguh-sungguh dalam mendenarkan materi yang diberikan oleh dosen. Adapun beberapa mahasiswa yang mengeluh tentang pembelajaran secara daring ini adanya tugas yang dikatakan cukup banyak serta tanpa pemberian penjelasan tentang materi yang cukup sehingga sehingga mahasiswa merasa kesulitan dalam mengerjakan tugas yang di berikan oleh dosen, hal ini dapat mengakibatkan pembelajaran tidak berjalan evektif. Seharusnya mahassiswa bisa mengembangkan minat belajar dengan bakat yang mahasiswa punya, Mahasiswa juga membutuhkan bimbingan dan arahan dari dosen. Dalam pembelajaran daring mahasiswa juga dituntut untuk bekajar secara mandiri dan harus mampu memahami materi dengan baik, agar meateri yang di berikan dosen kepada mahasiswanya tidak keliru. Mahasiswa juga mengeluh dalam pembelajaran daring sehingga mahasiswa memilih untuk belajar secara tatap muka. Disaat pandemic saat ini mahasiswa juga di himbau untuk tidak menjadi ptibadi yang individu. Melalui proses belajar secara online dosen dan mahasiswa dihimbau untuk dapat memberi pengetahuan yang lebih banyak dan secara luas melalui orang yang ahli di bidangnya ataupun diluar bidangnya dengan pemanfaatan penggunaan teknologi.

Dengan pembelajaran daring, mahasiswa bisa mengikuti dimana saja sehingga mudah bagi mahasiswa untuk mengikutin pembelajaran secara daring, dengan waktu yang telah di tetapkan oleh sekolah masing-masing. Dengan pembelajaran daring,dosen memberikan materi metri melalui berbagai aplikasi sehingga mahasiswa mudah untuk mengikuti keas-kelas daring ini. Kelebihan lain pada saat pembelajaran daring yaitu mampu menumbuhkan berbagai kemandirian bagi mahasiswwa, pembelajaran daring lebih berpusat kepada mahasiswa yang mampu memunculkan tanggung jawab dalam melakukan pembelajar. Demokrasi adalah sistem pembelajaran yang paling tepat dalam mengatasi pandemic covid-19 ini. Hanyalah melalui demokrasi,media bebas dapat menjalankan peran mereka dalam memberikan informasi mengenai kasus covid29 dengan benar dan akurat kepada masyarakat luas, serta mengawasi kinerja pemerintah dan lembaga negara dalam menangani pandemic covid-19 serta melawan berbagai macam disindormasi yang dapat memecah belah masyarakat. Pandemi covid19 membuat mahasiswa untuk bisa saling tolong menolong, dan saling memahami satu sama lain, jangan sampai memperkeruh suasana. Disisi masyarakat juga harus mematuhi kewajugan dengan mematuhi protocol kesehatan maka masyarakat sudah membantu pemerintah dan tenaga medis. Di detiap kegiatan masyarakat juga dihimbau untuk saling bekerja sama, dan bergotong royong dalam menanggapi masalah seperti ini.

\section{DAFTAR PUSTAKA}

Amira Soraya (30 juni 2020, pukul 04:32), "aktualisasi demokrasi pancasila ditengah pandemic ", https://www.kompasiana.com/amirani47 696/5efa5890097f3609332cf0b2/aktualis asi-demokrasi-pancasila-di-tengahpandemi?page $=$ all \#

Argaheni, N. B. (2020). Sistematik Review: Dampak Perkuliahan Daring Saat Pandemi COVID-19 Terhadap Mahasiswa Indonesia. PLACENTUM: Jurnal Ilmiah Kesehatan Dan Aplikasinya, 8(2), 99-108. https://doi.org/10.20961/placentum.v8i2. 43008

Dr. Gisheila Ruth Anggitha (2020), "upaya kesehatan masyarakat dalam menghadapi pandemic virus corona".

https://www.alomedika.com/cme-upayakesehatan-masyarakat-dalammenghadapi-pandemi-virus-corona

Dwi, B., Amelia, A., Hasanah, U., \& Putra, A. M. (2020). Analisis Keefektifan Pembelajaran Online di Masa Pandemi Covid-19. Jurnal Pendidikan Guru Sekolah Dasar, 2 (1), 3.

Elsa Damayanti (17 April 2020), "Apa kabar mahasiswa dengan kuliah daringnya?", 
https://muda.kompas.id/baca/2020/04/17

lapa-kabar-mahasiswa-dengan-kuliahdaaringnya/.

Firman. (2020). Dampak Covid-19 terhadap Pembelajaran di Perguruan Tinggi. Bioma, 2(1), 14-20.

Ich@(23-7-2020), "Dampak pandemic covid19 bagi mahasiswa", https://perpustakaan.iaintulungagung.ac.id/.

Karlina, S., Nurfaridah, W. O., Lasambouw, C. M., Bandung, P. N., \& Kunci, K. (2020). Penerapan Nilai-Nilai Pancasila di Kalangan Mahasiswa dalam Melaksanakan Kebijakan Pemerintah dalam Bidang Pendidikan di Era Pandemi Covid-19, 26-27.

Mellynia, R., Trisiana, A., Viyani, N. N., Safitri, F., \& ... (2020). Bersatu Melawan Covid 19 Dengan Hidup Sehat Dalam Perspektif Pendidikan Kewarganegaraan. Jurnal Global Citizen Jurnal Ilmiah, 9(1), 24-38. Retrieved from http://ejurnal.unisri.ac.id/index.php/glbct z/article/view/3882

Raden Muhammad rihardi,(08/06/2020,14:38 wib), "tubuh demokrasi di lorong pandemic".

https://nasional.kompas.com/read/2020/0 6/08/14382521/tubuh-demokrasi-dilorong-pandemi?page $=$ all

Samhis setiawan (2020), " Studi kepustakaan adalah?",

https://www.gurupendidikan.co.id/studikepustakaan/.

Santika, I. W. E. (2020). Pendidikan Karakter pada Pembelajaran Daring. Indonesian Values and Character Education Journal, 3(1), 8-19.

"Sebuah seruan untuk membela Demokrasi", https://www.ndi.org/sites/default/files/A $\% 20$ Call\%20to\%20Defend\%Democracy -Indonesian.pdf

Setiawan, A. R., Puspaningrum, M., \& Umam, K. (2019). Pembelajaran Fiqh Mu'Āmalāt Berorientasi Literasi Finansial. TARBAWY: Indonesian Journal of Islamic Education, 6(2), 187192.

https://doi.org/10.17509/t.v6i2.20887
Widiyono, A. (2020). Efektifitas Perkuliahan Daring (Online) pada Mahasiswa PGSD di Saat Pandemi Covid 19. Jurnal Pendidikan, 8(2), 169-177. https://doi.org/10.36232/pendidikan.v8i2 .458

Windhiyana, E. (2020). Dampak Covid-19 Terhadap Kegiatan Pembelajaran Online Di Perguruan Tinggi Kristen Di Indonesia. Perspektif Ilmu Pendidikan, 34(1), 1-8. https://doi.org/10.21009/pip.341.1

Watnaya, A. kusnayat, Muiz, M. hifzul, Nani Sumarni, Mansyur, A. salim, \& Zaqiah, Q. yulianti. (2020). Pengaruh Teknologi Pembelajaran Kuliah Online Di Era Covid-19 Dan Dampaknya Terhadap Mental Mahasiswa. EduTeach: Jurnal Edukasi Dan Teknologi Pembelajaran, 1(2), 153-165. https://doi.org/10.37859/eduteach.v1i2.1 987

Zhafira, N. H., Ertika, Y., \& Chairiyaton. (2020). Persepsi Mahasiswa Terhadap Perkuliahan Daring Sebagai Sarana Pembelajaran Selama Masa Karantina Covid-19. Jurnal Bisnis Dan Kajian Strategi Manajemen, 4, 37-45.

Thomas Aquinas Sandy Enggar Pitoyo( senin 6 april 2020, pukul 11:00 wib, "antara covid,mahasiswa dan kampus" https://news.unika.ac.id/2020/04/antarac ovid19mahasiswadankampus/. 